\title{
Coral-feeding wrasse scars massive Porites colonies
}

Received: 6 August 2008/Accepted: 8 August 2008/Published online: 28 August 2008

(C) Springer-Verlag 2008

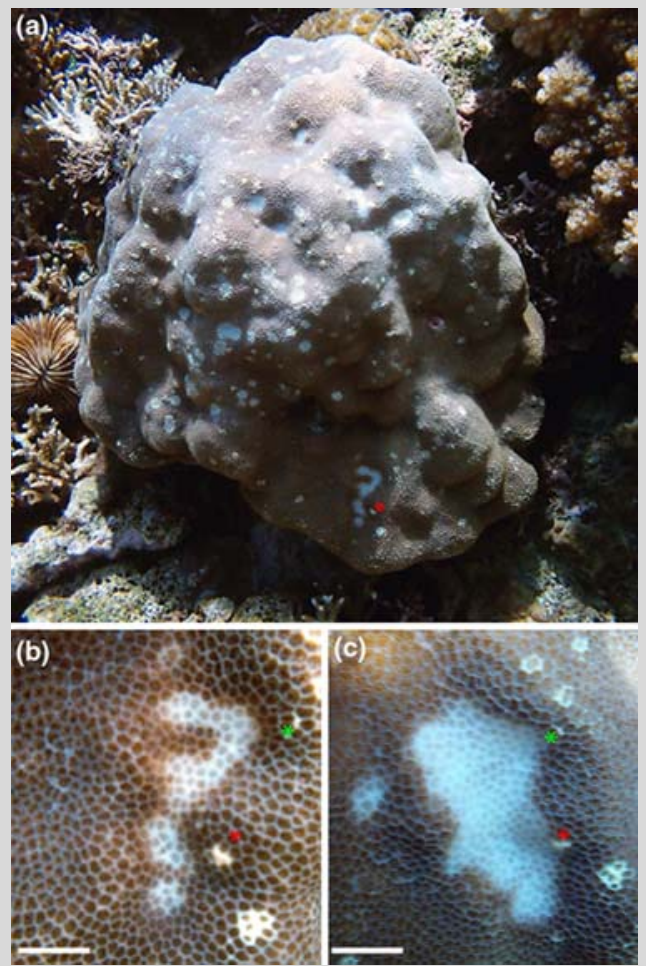

Fig. 1 (a) Massive Porites colony showing typical scarring following predation by L. unilineatus. (b) Expansion of feeding scar over a 4-h period, photo taken at 10 a.m. and (c) $4 \mathrm{~h}$ later. Scale bar $20 \mathrm{~mm}$. Asterisks identify the same polyp
Coral-feeding fish can be broadly categorised into polyp and skeletal feeders. Skeletal feeders (e.g. Scarids, Tetraodontids) remove coral skeleton in addition, to coral tissue and can have dramatic influences on the coral community (Cox 1986). In contrast, most coral-feeding fish remove coral polyps and mucous without harming the underlying corallite, thus leaving no visible evidence of predation. This has subsequently led to the assumption that polypfeeding fishes have only minor impact on prey corals (reviewed by Cole et al. 2008). However, in Kimbe Bay, Papua New Guinea, intense predation by the mucous feeding tubelip wrasse, Labrichthys unilineatus leads to distinct feeding scars on massive Porites colonies. Individual fish were observed to rapidly mouth the coral and repeatedly returned to the exact same point to feed presumably to exploit excess mucous production following the initial injury (McIlwain and Jones 1997). This repetitive mouthing left conspicuous white circular marks. Most scars were small, typically less than $1 \mathrm{~cm}$ in diameter (Fig. 1a). However, larger scars were occasionally observed. One such scar was monitored, where at least eight larger $L$. unilineatus individuals $(8-12 \mathrm{~cm} \mathrm{TL})$ repeatedly fed in the same exact location, causing visible expansion of this scar $\left(\approx 8 \mathrm{~cm}^{2}\right)$ over a 4 -h period (Fig. $\left.1 \mathrm{~b}, \mathrm{c}\right)$.

Not all massive Porites colonies had feeding scars, however, when scars were observed they were usually numerous (Fig. 1). The relatively flat, two-dimensional surface of massive Porites colonies may enable $L$. unilineatus to feed more efficiently and remove a greater amount of tissue per bite compared to more complex branching species. The energetic cost of chronic predation by small piscine corallivores is often considered to be negligible, but extensive tissue loss as observed on Porites colonies will clearly require considerable investment in repair and may facilitate the establishment of disease or epibionts (e.g. Spirobranchus giganta).

\section{References}

Cole AJ, Pratchett MS, Jones GP (2008) The diversity and functional importance of coral-feeding fishes on tropical coral reefs. Fish Fish 9:286-307

Cox EF (1986) The effects of a selective corallivore on growth rates and competition for space between two species of Hawaiian corals. J Exp Mar Biol Ecol 101:161-174

McIlwain JL, Jones GP (1997) Prey selection by an obligate coral-feeding wrasse and its response to small-scale disturbance. Mar Ecol Prog Ser 155:189-198

A. J. Cole $(\bowtie) \cdot$ M. S. Pratchett · G. P. Jones

ARC Centre of Excellence for Coral Reef Studies, James Cook University, Townsville Q4811 QLD, Australia e-mail: andrew.cole3@jcu.edu.au

A. J. Cole · M. S. Pratchett · G. P. Jones

School of Marine and Tropical Biology, James Cook University, Townsville Q4811 QLD, Australia

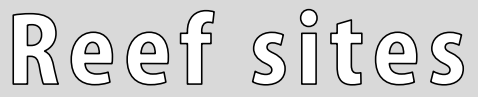

Coral Reefs (2009) 28:207

DOI $10.1007 / \mathrm{s} 00338-008-0415-2$ 